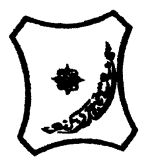

Bayero Journal of Pure and Applied Sciences, 10(1): 493 - 497

ISSN $2006-6996$

\title{
CHARACTERIZATION AND COMPOSITION ANALYSIS OF MUNICIPAL SOLID WASTE IN KANO, NIGERIA
}

\author{
Salamatu A. Afuno and Safianu Rabiu \\ ${ }^{1}$ Department of Biological Science, Bayero University, 1 Gwarzo Road, \\ P.M.B 3011, Kano 700241, Nigeria \\ zakirai@gmail.com
}

ABSTRACT

Municipal Solid Waste (MSW) is produced through human activities and in the last two decades, management of MSW has become a major concern due to considerable increase in its production. The amount of MSW produced increases with economic growth and this demands for efficient solution. This paper reports the characterization and composition analysis of MSW in Kano metropolis. Solid waste samples were collected and analysed from the four major dumpsites in Kano metropolis during the months of September, 2016- January, 2017. The results showed that light plastic had the highest mean values of $8.63 \mathrm{~kg} / 50 \mathrm{~kg}$ sample, Organics $7.22 \mathrm{~kg} / 50 \mathrm{~kg}$, Heavy plastic $4.15 \mathrm{~kg} / 50 \mathrm{~kg}$, Fabric $3.91 \mathrm{~kg} / 50 \mathrm{~kg}$, paper $2.70 \mathrm{~kg} / 50 \mathrm{~kg}$, metal $2.05 \mathrm{~kg} / 50 \mathrm{~kg}$, glass $1.89 \mathrm{~kg} / 50 \mathrm{~kg}$, Bone $1.47 \mathrm{~kg} / 50 \mathrm{~kg}$, styrofoam $0.19 \mathrm{~kg} / 50 \mathrm{~kg}$, others $1.06 \mathrm{~kg} / 50 \mathrm{~kg}$ and wood $-0.25 \mathrm{~kg} / 50 \mathrm{~kg}$. There was significant correlation between estimated population and volume of trash collected. We offered suggestion for effective management strategies and efficient policies for waste reduction, disposal and recycling practices.

Keywords: Waste Characterization, Municipal Solid Waste, Waste Composition, Kano, Nigeria

INTRODUCTION

Solid waste is broadly comprised of nonhazardous domestic, commercial and industrial refuse including household organic waste, hospital and institutional garbage, street sweepings and construction waste (Zerbock 2003). Domestic solid waste includes all wastes generated in the community and generally includes food scraps, containers and packaging, discarded durable and non durable goods, yard trimmings, miscellaneous inorganic debris and often construction and demolition debris. Municipal solid waste (MSW) consists of domestic waste generated by urban residents (household) with addition of commercial wastes but typically excludes industrial hazardous waste and domestic sewage sludge (James, 1997). MSW includes durable goods, nondurable goods, containers and packaging wastes, food wastes and yard trimmings and miscellaneous inorganic wastes. Thus MSW is an accumulation of rejects from household, market women, trades, shop owners and other commercial activities in the urban areas (US EPA 2011).

The composition and characteristics of MSW is influenced by certain factors which includes the area (residential, commercial etc) the economic level (differences between high and low incomes area) season and weather (difference in the amount of population during the year, tourist places and culture of people living or doing business in the area). High income areas usually produce more inorganic materials such as plastics and paper, while low
- income area produce relatively more of organic waste. Uncontrolled or improperly sited open solid waste dumpsites constitute health hazards and damage the aesthetic beauty of many cities in Nigeria (Napoleon et al., 2011). It has been estimated that Kano Municipal generates about 156.678 tones of solid waste per month and with a population of about $3,242,700$ the per capita solid waste generation is about $0.56 \mathrm{~kg} /$ capita/day (Ogwueleka, 2009). This makes Kano city second to Lagos in terms of waste generation in Nigeria. Waste characterization data consists of information on the types and amount of materials (which includes food waste, yard trimming, paper, glass, etc) in the waste stream. Characterization of municipal solid waste is a fundamental component in proper planning of solid waste management in any urban city. It helps in determining the quantity of waste generated in a particular location at a particular time of the year. Nigeria with a population of 140 million (2006 census) generates about 25million tones of MSW per annum with a generation ranging from $0.44 \mathrm{~kg} /$ Capita/Day - $0.66 \mathrm{~kg} /$ Capita/day. Solid waste management has emerged as one of the greatest challenges facing state and local government environmental protection agencies in Nigeria. Solid Waste Management in Nigeria is characterized by inefficient collection method, insufficient coverage of the collection system and improper disposal of the waste (Ogwueleka, 2009). 
Special Conference Edition, November, 2017

In Kano metropolis like most cities in the developing world several tones of municipal solid waste is left uncollected on the streets each day, clogging drains, creating feeding grounds for pest that spread disease and creating a myriad of related health and infrastructural problem. A substantial part of the urban resident in the old city and sub urban informal settlements of Kano metropolis also has little or no access to solid waste collection services. This is due to lack of proper land use planning which resulted in creation of informal settlement with narrow streets that makes it difficult for collection trucks to reach many areas. The result is that a large portion of the population is left without access to solid waste management making them particularly vulnerable (Nabegu, 2008). Some studies have been carried out on waste management in Kano metropolis. Saleh (2008) studied the contributions made by scavengers and showed that over 25,000 people are directly involved in the activity and that $15 \%$ of municipal solid waste that would have gone into the municipal solid waste stream is removed by them.

Recycling has been viewed as a veritable tool in minimizing the amount of household solid wastes that enter the dump sites. It also provides the needed raw materials for industries. According to them, it has been established that it is the best, efficient method of solid waste management system. However, this may not be cost effective in developing countries like Ghana (Momoh and Oladebeye, 2010, United State Environmental Protection Agency, 2011, Bundela et al., 2010).

The objectives of this paper were to determine the categories of waste trash items, the volume and mass of trash and any relationship between trash volume and population size estimates in the selected communities of Kano Municipality.

\section{MATERIALS AND METHODS}

Study area:

Kano is the largest city in the Sudan Region of Nigeria. It is located between latitude $12^{0} 25$ to $12^{0} 40 \mathrm{~N}$ and longitude $8^{0} 35 \mathrm{~N}$ to $8^{0} 45 \mathrm{E}$. Kano city has for centuries been the most important commercial and industrial nerve centre of Northern Nigeria attracting millions from all parts of the country and beyond. Immigration and natural growth rate of $3 \%$ is expected to continue to increase the population and waste stream in the years to come. With a population presently estimated at 3.5 milliom, Kano metropolis is among the fastest growing cities in Nigeria. With a population density of about 1000 inhabitant per $\mathrm{Km}^{2}$ within the Kano closed - settled zone compared to the National average of 267 inhabitants per $\mathrm{Km}^{2}$. It also has a large migrant worker population which has been increasing at the rate of 30 to 40 percent per annum (UNDP 2004).

\section{Sampling Sites:}

Locations of waste disposal in the four government designated dumpsites within the metropolis; namely Court Road, Hajj Camp, Ubagama and Maimalari are shown in (fig 1). Court road dumpsite constitutes waste from various collection centers mostly residential and service from some parts of Tarauni, Kumbotso and Nassarawa local government areas. Hajj Camp dumpsite constitute waste from residential, industry and service neighborhoods. These come from collection centres from parts of Fagge, Nassarawa, Dala and Gwale Local Government Areas. While Maimalari dumpsite serves industrial, service and also residential area from parts of Nassarawa, Fagge and Gwale Local Government Areas. Ubagama being the smallest in term of tonnage serves some parts of Dala, Kano Municipal Council and Gwale Local Government Areas.

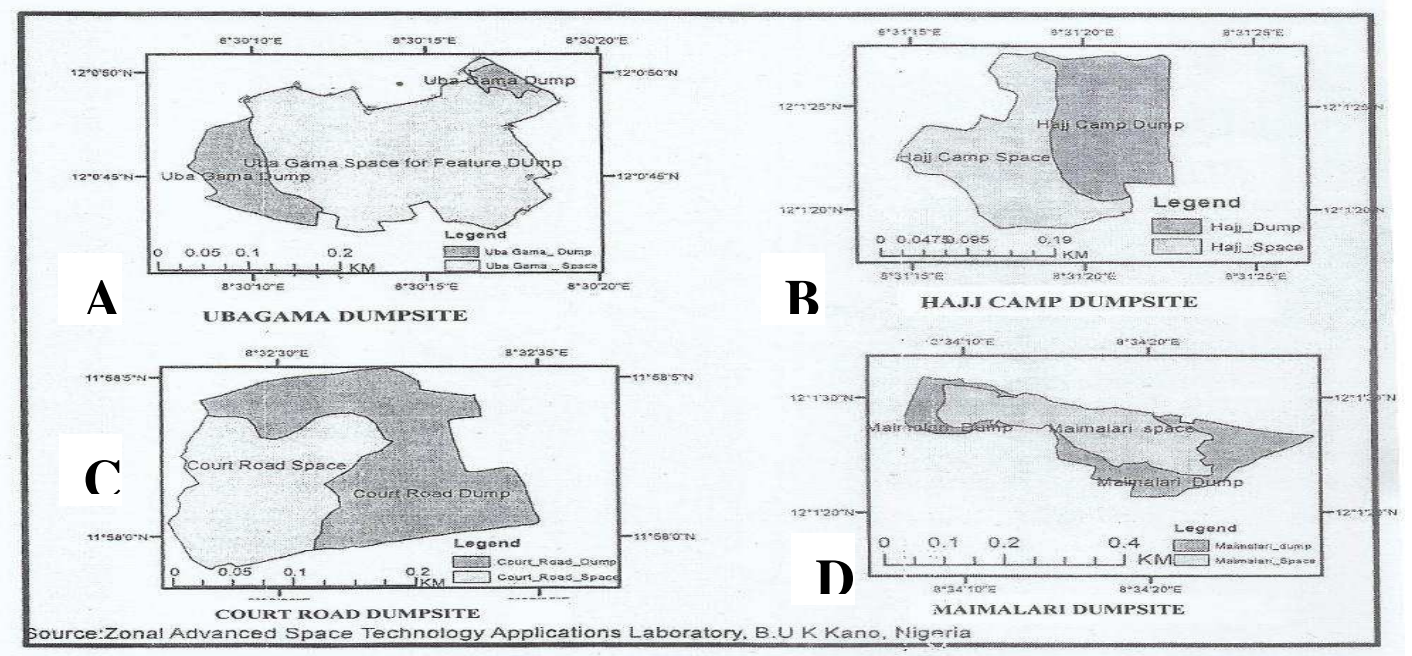

Fig 1: Specific dumpsites sampled 


\section{Special Conference Edition, November, 2017}

Thus, because of the mix in thrash sources, the waste in the four dumpsites do not quite reflect social or material status.

Sample Collection and Waste Characterization Data for waste dumps in Kano metropolis and other related documents were obtained from Kano State Refuse Management and Sanitation Board (REMASAB). Estimated human population data was obtained from National Population Commission.

Characterization of waste was carried out according to the American Society for testing and materials (ASTM, 1998). Five samples (randomly collected) of $10 \mathrm{~kg}$ each, totaling $50 \mathrm{~kg}$ of solid waste sample were collected during each of four sampling periods from each of the dumpsites. The samples were then sieved to remove sand, followed by hand picking in order to remove stones which would not pass through the sieves, after which the sample was spread on a $2 \times 3$ Meter polythene sheet before sorting into eight different categories namely: plastic (light and heavy plastic), metal, glass, paper, fabric, stereofoam, organics (which comprises of waste that comes from plants or animals sources such as food waste, fruits and vegetables peel, grass, etc) and others. Each category was placed inside a labelled plastic container and was weighed. The sample was then taken to the laboratory where some of the categories; organic, paper and fabric were put in oven for drying at $80-90^{\circ} \mathrm{C}$ for $48 \mathrm{hrs}$ after which the sample was allowed to rest for 2 days (cooling time). After cooling, the sample was again weighed and its dry mass was recorded. The remaining categories that had no moisture content were air dried, and dry mass taken. This procedure was carried out for samples taken from each visit (five visits) for each of the four dumpsites for the duration of six months.

\section{RESULTS AND DISCUSSIONS}

Mean dry mass per $50 \mathrm{~kg}$ of 20 samples from each of the four sampling sites are given in table 1 . The values ranged from $3.32 \mathrm{~kg} / 50 \mathrm{~kg}$ at Ubagama to $4.20 \mathrm{~kg} / 50 \mathrm{~kg}$ at Hajj Camp site (Table 1).

Table 1: mean dry mass per $50 \mathrm{~kg}$ of 20 samples from each of the study sites.

\begin{tabular}{lll}
\hline Site & Mean Mass & SE Mean \\
\hline Court Road & 3.92 & 0.83 \\
Hajj Camp & 4.20 & 1.24 \\
Maimalami & 3.33 & 0.52 \\
Ubagama & 3.32 & 0.38 \\
\hline
\end{tabular}

The mean values of dried thrash category items are compared in table 2 . Items with differing letters were significantly different. These include light plastics, glass and metals. It appeared that certain categories of trash had significantly greater mass than others, a finding consistent with similar studies (Bundela et al., 2010; Saleh, 2008)

Table 2: Tukey Pairwise Comparisons: Category Grouping Information Using the Tukey Method and 95\% Confidence

\begin{tabular}{lrrll}
\hline Category & $\mathrm{N}$ & Mean & Grouping \\
\hline Light Plastic & 15 & 8.63482 & $\mathrm{~A}$ & \\
Organics & 15 & 7.22186 & $\mathrm{~A}$ & $\mathrm{~B}$ \\
Heavy Plastic & 15 & 4.15487 & $\mathrm{~A}$ & $\mathrm{~B}$ \\
Fabric & 15 & 3.91482 & $\mathrm{~A}$ & $\mathrm{~B}$ \\
Paper & 20 & 2.70187 & $\mathrm{~A}$ & $\mathrm{~B}$ \\
metal & 5 & 2.05767 & $\mathrm{~A}$ & $\mathrm{~B}$ \\
Glass & 18 & 1.89483 & & $\mathrm{~B}$ \\
Bone & 5 & 1.47778 & $\mathrm{~A}$ & $\mathrm{~B}$ \\
Others & 1 & 1.06670 & $\mathrm{~A}$ & $\mathrm{~B}$ \\
Metal & 10 & 0.52652 & & $\mathrm{~B}$ \\
Styro form & 6 & 0.19453 & $\mathrm{~A}$ & $\mathrm{~B}$ \\
Wood & 4 & -0.25118 & $\mathrm{~A}$ & $\mathrm{~B}$
\end{tabular}

Means that do not share a letter are significantly different. 
Special Conference Edition, November, 2017

A regression plot for trash volume and populations size is given in fig 2 .

Pearson correlation for 2016 population

estimates versus trash volume was 0.60
$(P<0.05)$ positive and significant. $A$ general regression for trash volume versus population estimates was also significant $(f=9.69 ; P<0.05)$

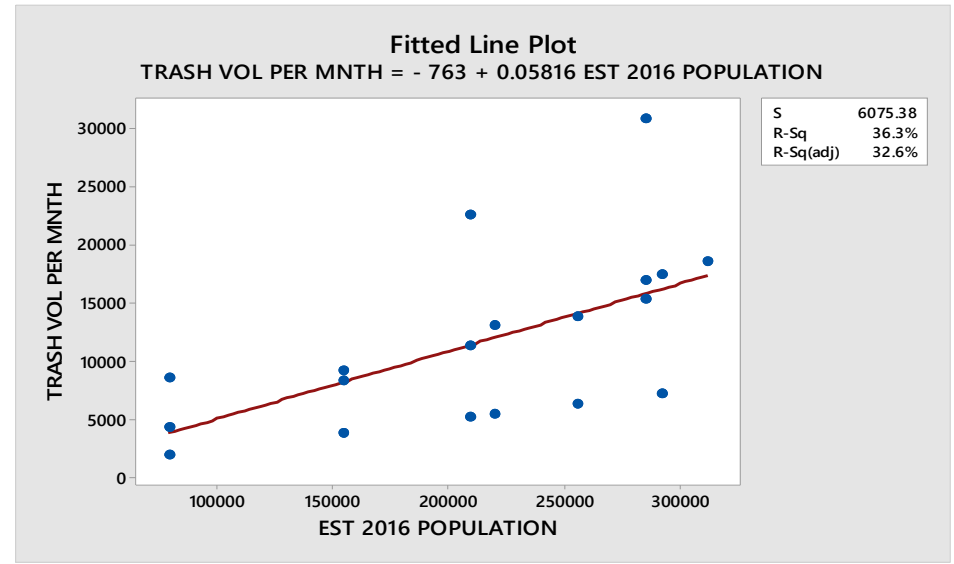

Fig 2: Regression for monthly Trash Volume and 2016 populations estimated

Table trash, category and site of collection on mean dry mass of the trash. Only the type of trash (category) appeared to have any influence on dry mass of the trash. Months and site differences had no effect on thrash mass (Table 3). 3 shows results from the robust general linear model for analysis of variance for the effect of month

Table 3: General Linear model: Analysis of variance-dry mass versus months, category and site

\begin{tabular}{lrrrrr}
\hline Source & DF & Adj SS & Adj MS & F-Value & P-Value \\
\hline Time/Month & 4 & 73.14 & 18.28 & 0.76 & 0.553 \\
Category & 17 & 995.82 & 58.58 & 2.44 & 0.003 \\
Site & 3 & 74.10 & 24.70 & 1.03 & 0.383 \\
Error & 129 & 3101.90 & 24.05 & & \\
Lack-of-Fit & 96 & 2667.22 & 27.78 & 2.11 & 0.008 \\
Pure Error & 33 & 434.68 & 13.17 & & \\
Total & 153 & 4214.44 & & & \\
\hline
\end{tabular}

Population size had impact on the composition of wastes as shown in figure 2. Such correlations have been noted by Ogwueleka (2009). Thus, trash volume can be predicted based on population size.

The absence of significant differences in thrash composition or mass between the months showed the absence of seasonal differences in people's consumption habits. There were no differences amongst the different neighborhoods in respect to trash volume generated. (Table 1)

According to Zurbrugg (1999) waste generation is conditioned to an important degree by people's attitude towards waste especially their patterns of material use and waste handling; their interest in waste reduction and minimization; the degree to which they separate wastes and extent to which they refrain from indiscriminate dumping and littering. We could not establish similar observation because trash from different neighborhoods were mixed up in the same site. Moreover, scavengers had probably done away with some desired items soon as the trash was dumped. That sites or months made no significant difference in trash volume received which might probably be as a result of trash shifting by the authorities for the purpose of landfilling.

\section{CONCLUSION}

The characteristics and composition analysis of municipal solid waste in Kano metropolis was conducted in the four major dumpsites serving eight metropolitan local government areas. The results showed that light plastic had the highest mean values of $8.63 \mathrm{~kg} / 50 \mathrm{~kg}$ sample, Organics $7.22 \mathrm{~kg} / 50 \mathrm{~kg}$, Heavy plastic $4.15 \mathrm{~kg} / 50 \mathrm{~kg}$, Fabric $3.91 \mathrm{~kg} / 50 \mathrm{~kg}$, paper $2.70 \mathrm{~kg} / 50 \mathrm{~kg}$, metal $2.05 \mathrm{~kg} / 50 \mathrm{~kg}$, glass $1.89 \mathrm{~kg} / 50 \mathrm{~kg}$, Bone $1.47 \mathrm{~kg} / 50 \mathrm{~kg}$, styrofoam $0.19 \mathrm{~kg} / 50 \mathrm{~kg}$, others $1.06 \mathrm{~kg} / 50 \mathrm{~kg}$ and wood $-0.25 \mathrm{~kg} / 50 \mathrm{~kg}$. 


\section{Special Conference Edition, November, 2017}

The result clearly suggests the need for more effective management policy for solid waste, the need to put it to some use by recycling or reducing it. There is really a need for policies for waste reduction, disposal and recycling practices. Waste recycling can be promoted

\section{REFERENCES}

ASTM, "Standard Test Method for Determination of the composition of unprocessed Municipal Solid Waste", ASTM Standard D 5231-5292 (Reapproved 1998). American Society for Testing and Materials US.

Bundela P.S., Gautam S.P. Pandev A.K, Awasthi, MK and SarSaiya, S (2010). Municipal solid waste management in Indian cities - A review international journal of environmental sciences volume 1, No. 42010 pp. 591 - 606. http://210.212.96.131//rpcb/reportsan dpaper/mswmamitsingh PDF (retrieved April, 2011).

James, A. (1997). Riegel's Handbook of industrial chemistry. CBS Publishers and Distributors India.

Momoh, J.J and Oladebeye, D.H (2010). Assessment of Awareness of Attitude and Willingness of people to participate in household solid waste recycling programme in Ado-Ekiti, Nigeria in the Journal of Applied Sciences in Environmental Sanitation. Vol. 5 (1): 93-105

Nabegu A.B, 2008. An Assessment of refuse management and sanitation board (REMASAB) waste management in Kano metropolis. Techno-science Africana Journal, 1: 101-108.

Napoleon, S. Kingsley O. And Joan E. (2011). Mitigating the impact of solid wastes in through enlightenment campaigns to encourage people to cooperate in waste separation before disposal and also encourage them to purchase recycled products. Participation of private firms in collection, processing and disposal of waste is also recommended.

urban centres in Nigeria. Journal of Human Ecology 34(2): 125 - 133.

Ogwueleka, T.C., (2009) "Municipal solid waste characteristics and management in Nigeria". Iran Journal of Environment, health, Science and Engineering, 6(3): $173-180$.

Saleh GA (2008). Analysis of Savenging Activities and Reuse of Solid Wastes in Kano Metropolis, Nigeria. Unpublished $\mathrm{PhD}$ Thesis submitted to department of Geography, BUK.

United Nations Development Programme (UNDP) (2004). Municipal Solid Waste Management in Developing Countries: A Policy Framework. Geneva Technical Paper, 12. Geneva: UNDP.

US EPA (2011) Communicating the benefit of recycling. United States Environmental Protection Agency. Available at: www.epa.gov/osw/conserve/tools/loca lgov/benefits/index.htm

Zerbock, O. (2003). "Urban Solid Waste Management: Waste Reduction in Developing Nations". Unpublished MSC Thesis Michigan Technological University.

Zurbrugg C. (1999): The Challenge of Solid Waste Disposal in Developing Countries, EAWAG/SANDEC, Swiss Federal Institute for Environmental Science and Technology, Ueberlandstrasse 133, Switzerland. Pp 10-14 